Folia phoniat. 1983;35:81-86

\title{
IALP News
}

\section{Modifications to the IALP By-Laws}

Informative and consultative status (category B) with

UNESCO, UNICEF, WHO, ECOSOC and CIOMS

Folia phoniat. 35: 81-86 (1983)

As the by-laws of our Association have shown signs of age, the IALP Board has requested the By-Laws Committee (Prof. Loebell, chairman) to rewrite certain articles. We submit them hereby for the consideration of all our members. These amendments to our by-laws will be discussed and, hopefully, approved at the General Assembly in Edinburgh.

Current By-Laws

Adopted August 18, 1971

Proposed By-Law Changes

Article One: General (new)

Section 1. The International Association of Logo-pedics and Phoniatrics is a nongovernmental worldwide organization.

Section 2. The organization works for the benefit of the speech- and language-, voice- and hearing-handicapped.

Section 3. The organization has two major fields: Logopedics and Phoniatrics.

Section 4. The organization is nonpolitical.

Article One: Organization

Section 1. The name of this organization shall be International Association of Logopedics and Phoniatrics, Inc., abbreviated IALP in all languages.

Section 2. The organization shall have a seal which shall be in the following form:

Article Two: Organization Section 1. Unchanged.

Section 2. Unchanged.

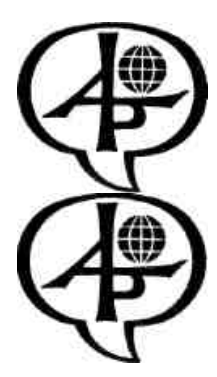

Section 3. The organization may change its name by a vote of the membership.

Section 3. Unchanged.

Section 4. Full particulars are given in 'Rules and Regulations'.

82

IALP News 
Article Two: Purposes

Article Three: Purposes

The following are the purposes for which this organization has been organized:

Section 1. To establish a center of information as to the state of Logopedics and Phoniatrics in various countries and to keep records thereof.

Section 2. To promote standards of training and medical, educational and scientific research in the field of Logopedics and Phoniatrics, i.e. human communication disorders (speech pathology, speech therapy, orthophony, phono-audiology, deaf-mutism, language pathology, etc.), in all countries and at all levels of the educational system.

Section 3. To organize periodical international congresses for exchanging the most recent knowledge in the field of Logopedics and Phoniatrics.

Section 4. To maintain and propagate an international journal dedicated to all questions of Logopedics and Phoniatrics.

Section 5. To establish contact with kindred scientific and therapeutical organizations and to assist in the establishment of such organizations in countries where there are none.

Section 6 . To encourage and promote a scientifically accurate and internationally recognized terminology in the field of Logopedics and Phoniatrics.

Section 7. To sponsor study groups engaging in research on specific items in the field of Logopedics and Phoniatrics.

Section 8. To secure international recognition for Logopedics and Phoniatrics as a special and separate science and to collaborate with UNESCO, UNICEF, WHO, ECOSOC and CIOMS. The following are the purposes for this organization:

Section 1. To promote development and standards of rehabilitative and preventive work, research and training in Logopedics and Phoniatrics, i.e. human communication disorders (speech and language, voice and hearing pathology, therapy and rehabilitation, orthophony, audiophonology, pedaudiology, etc.) in all countries and at all age levels.

Section 2. To distribute information on Logopedics and Phoniatrics in various countries and to keep records thereof.

Section 3. To organize periodic international congresses for the exchange of the most recent theoretical and practical knowledge in the field of Logopedics, Phoniatrics and Communication Pathology.

Section 4. Unchanged.

Section 5. Unchanged.

Section 6. To maintain international recognition for Logopedics and Phoniatrics as a special and separate science and to cooperate with UNESCO, UNICEF, WHO, ECOSOC and CIOMS, also as regards their practice of nondiscrimination with respect to race, national origin and religion.

Section 7. Cut.

Sections. Cut.

IALP News

83

Article Three: Membership

Section 1. Types of membership: 
Persons professionally engaged within the field of communication disorders and sciences may become Individual Members.

Persons and public and private corporations who are interested in promoting the aims of the Association may become Associate Members, without right to vote.

Multinational, national, regional or local organizations pursuing wholly or partly parallel purposes may become Affiliated Members, category A. Under special conditions Affiliated Members can belong to category $\mathrm{B}$, without any rights of vote.

Honorary Members. These shall be proposed by the Board ( $3 / 4$ majority) and elected by the General Assembly.

Section 2. The admission of a new individual member must be recommended by two individual members or by an affiliated society of his own country and approved by the Membership Committee, appointed by the Board of Directors. The admission of multinational, national, regional or local organizations as Affiliated Members requires the approval of the majority of the Board. Any member may at any time withdraw from the organization or may be suspended or expelled by the Board of Directors for any cause prejudicial to the best interests of the organization.

Section 3. Initiation fees and annual dues of the Individual Members shall be determined by the regular meeting of members on proposition of the Board of Directors. In case such fees or dues, owing to difficulties of currency regulations or for other reasons, cannot be determined on a general scale, the Board of Directors is entitled to settle the question of fees and dues for each country separately. The dues of the Affiliated Organizations will be determined by the Board of Directors in each case individually.

Article Four: Membership

Section 1. Types of membership:

Persons professionally trained within the field of communication disorders and sciences may become Individual Members.

Cut.

National organizations of Logopedics and Phoni-atrics may become Affiliated Members, category A. Multinational, regional or local organizations pursuing wholly or partly parallel purposes may become Affiliated Members, category B, without any rights of vote.

Corresponding and Honorary Members. These shall be proposed by the Board and elected by the General Assembly.

Section 2. Unchanged.

Section 3. Annual dues of the Individual Members shall be determined by the regular meeting of members on proposal of the Board of Directors. In case such dues, owing to difficulties of currency regulations or for other reasons, cannot be determined on a general scale, the Board of Directors is entitled to settle the question of dues for each country separately. The dues of the Affiliated Organizations will be determined by the Board of Directors in each case individually.

Article Four: Meetings

Section 1. Regular meetings of members to elect Directors as necessary, to receive the reports of the Directors and for the transaction of other business shall be held on the first Monday in July of each year, unless the Board of Directors resolves that the regular meeting

Article Five: Meetings 
Section 1. Regular meetings of members to elect Directors as necessary, to receive and discuss reports of the Directors and for the transaction of other business shall be held during each congress. Written notice thereof shall be mailed to each member not less than 84

IALP News

of members should be held at the occasion of, and at the same time as, the next congress. Written notice thereof shall be mailed to each member not less than 30, no more than 60 days before the meeting. Such notice shall state the purposes for which the meeting is called, and the time and the place where it is to be held.

Section 2. Special meetings of members may be called by the Board of Directors at any time and shall be called by the Board of Directors upon the written request of 50 members. Notice of special meetings shall be in the same manner as prescribed for the regular meeting.

Section 3. The Individual Members of the Association and the delegates of the Affiliated Societies form the voting body at the regular and special meetings. Every Individual Member and delegate is entitled to one vote. Members who cannot attend a special meeting may empower another member to vote for them. Except as otherwise provided in the by-laws, all action shall be decided upon by a majority vote.

Section 4. The order of business to be followed at the meetings shall be determined by the Board of Directors.

30, no more than 60 days before the meeting. Such notice shall state the purposes for which the meeting is called, and the time and the place where it is to be held.

Section 2. Unchanged.

Section 3. The Individual Members of the Association and the delegates of the Members, category A, form the voting body at the regular and special meetings. Every Individual Member and delegate is entitled to one vote. An Individual Member who is also a delegate is entitled to one vote only. Except as otherwise provided in the by-laws, all action shall be decided upon by a majority vote.

Section 4. Unchanged.

\section{Article Five: Directors}

Section 1 . The property and business of the IALP corporation and the management of its affairs shall be vested in the Board of Directors.

Section 2. At the first regular meeting of members, Directors numbering within the limits provided in the Certificate of Incorporation shall be elected to replace the Directors named in the certificate. They shall form the Board of Directors and serve until new Directors are elected at the next regular meeting of members. Directors may be reelected only twice in succession. The Secretary, however, may continue to be a member of the Board until a new Secretary is elected. The term of office is from one congress to the next.

Section 3. The Board of Directors shall have control of the property and affairs of the organization and shall fix its policies. They shall have power to hold meetings, organize committees, employ the necessary staff, accept, suspend or expel members as provided in the bylaws, authorize proper expenditures, and to take all necessary and proper steps to carry out the purpose of this organization and promote its best

Article Six: Directors Section 1. Unchanged. 
Section 2. At the first regular meeting of members, during a congress, a new Board of Directors shall be elected and serve until the next congress. The number of Directors shall be 15 . The term of office is from one congress to the next.

Section 3. The Board of Directors shall have control of the property and affairs of the organization and shall fix its policies. They shall have power to hold meetings, organize committees, employ the necessary staff, accept, suspend or expel members as provided in the bylaws, authorize proper expenditures, and to take all necessary and proper steps to carry out the purpose of this organization and promote its best

IALP News

85

interests. The Board of Directors may make such rules and regulations covering its meetings as it may in its discretion determine necessary for the best interests of the organization.

Article Six: Officers

Section 1. The Founder and Life President of Honour is Emil Froeschels, MD.

Section 2. The officers of the corporation shall consist of the President, the Immediate Past President, three Vice-Presidents, the Secretary and the Treasurer. The President shall be elected by the General Assembly. The other officers shall be elected by the Board of Directors from among its members. The powers and duties of the officers shall be as follows:

President: The president shall preside at all regular and special meetings of the Board of Directors and of the members of the corporation; he shall be the President of the Congresses; he shall appoint all committees, with the consent and approval of the Board of Directors; he shall sign all contracts in the name of the corporation; enforce these by-laws; cause all books and records to be properly kept and cause all meetings to be called as herein provided. He shall finally present at the regular meeting the verified report required by Par. 46 of the Membership Corporations Law, and such other report as he may deem necessary.

Vice-Presidents: The Vice-Presidents shall perform the duties of the President in case of necessity, by resolution of the Board. The Board of Directors shall determine which VicePresident shall function as acting President in a particular period.

Secretary: The Secretary shall serve all notices required by law or these by-laws; he shall keep minutes of all meetings, conduct the correspondence of the corporation; he shall keep the membership informed; keep the corporate seal and perform all the customary duties of a secretary.

Treasurer: The Treasurer shall receive and deposit in a bank, to be approved by the Board, all the monies of the corporation and keep an accurate account thereof; make disbursements only upon proper vouchers signed by the President or a Vice-President, sign

interests. The Board of Directors shall make such rules and regulations covering the details of IALP organization and meetings as it determines necessary for the best interests of the association.

Article Seven: Officers Section 1. Cut.

Section 1. The officers of the corporation shall consist of the President, the President Elect, the Immediate Past President, three Vice-Presidents, the Secretary and the Treasurer. The President Elect and the Vice-President in charge of the next congress shall be elected by the General Assembly. The other officers shall be elected by the Board of Directors from among its members. The powers and duties of the officers shall be as follows: 
President: The President shall preside at all regular and special meetings of the Board of Directors and of the members of the corporation; he shall be the President of the Congresses; he shall appoint all committees, with the consent and approval of the Board of Directors; he shall sign all contracts in the name of the corporation; enforce these by-laws; cause all books and records to be properly kept and cause all meetings to be called as herein provided. At all regular membership meetings he shall schedule the presentation of the triennial reports of the Secretary and Treasurer, and other reports deemed necessary.

President Elect: The President Elect shall perform duties designated by the President and the Board of Directors. In the case of necessity, the Board of Directors shall determine which VicePresident shall function as acting President or President Elect in a particular period.

Secretary: Unchanged.

Treasurer: The Treasurer shall receive and deposit in a bank, to be approved by the Board, all the monies of the corporation and keep an accurate account thereof; make special disbursements only upon proper vouchers signed by the President or the Secretary, sign

86

IALP News

checks, make the financial reports of the corporation and perform all the customary duties of a treasurer.

Section 3. No officer shall receive any salary or compensation, except compensation for disbursements made upon instruction ofthe Board of Directors.

Article Seven: Committees

Section 1. Membership Committee: The Membership Committee shall review all applications for membership and shall decide about the admission. The Membership Committee is designated by the President on proposition of the Board of Directors.

Section 2. The Committee of Delegates: The Committee of Delegates is a consulting body, consisting of delegates from each affiliated society and the members of the Board of Directors. The number of delegates eligible to represent each affiliated association will be decided by the Board of Directors prior to each congress. It meets during the congress of the Association and discusses all questions relating to the activities of the Association. Representatives of countries who have no society affiliated with IALP may attend the Delegates' Meeting, without rights to vote.

Section 3. The National Committee of Organization of the Congress is presided by one of the Vice-Presidents of the Association, who should be elected in the previous General Assembly from among persons who reside in the country where the congress will take place. The Chairman ofthe National Committee of Organization ofthe Congress is the host ofthe Congress; he chooses and directs the members of the National Committee.

checks, make the financial reports of the corporation and perform all the customary duties of a treasurer.

Section 2. Unchanged.

Article Eight: Committees Section 1. Unchanged.

Section 2. The Committee of Delegates: The Committee of Delegates is a consulting body, consisting of delegates from each affiliated Member, category A, and the members ofthe Board of Directors. The number of delegates eligible to represent each affiliated associa-ion will be stated in the 'Rules and Regulations'. It meets during the congress of the Association and discusses all questions relating to the activities of the Association. Members category B and 
representatives of countries who have no society affiliated with IALP may attend the Delegates' Meeting without rights to vote.

Section 3. Unchanged.

Article Eight: Amendments

These by-laws or any part thereof may be amended, repealed or changed by the vote of a majority ofthe voting members at any regular meeting or special meeting called for the purpose, provided, however, that a copy of the proposed change be mailed to the individual members and affiliated societies at least thirty days before the meeting called to consider the same.

Article Nine: Amendments Unchanged. 